\title{
Urban Foraging in Berlin: People, Plants and Practices within the Metropolitan Green Infrastructure
}

\author{
Jonah L. Landor-Yamagata ${ }^{1}$, Ingo Kowarik ${ }^{1,2}$ (D) and Leonie K. Fischer ${ }^{1,2, *(1)}$ \\ 1 Department of Ecology, Ecosystem Science/Plant Ecology, Technische Universität Berlin, Rothenburgstr. 12, \\ D-12165 Berlin, Germany; jonah.ly@gmail.com (J.L.L.-Y.); kowarik@tu-berlin.de (I.K.) \\ 2 Berlin-Brandenburg Institute of Advanced Biodiversity Research (BBIB), D-14195 Berlin, Germany \\ * Correspondence: leonie.fischer@tu-berlin.de; Tel.: +49-30-31471487
}

Received: 16 May 2018; Accepted: 2 June 2018; Published: 4 June 2018

\begin{abstract}
Gathering wild plants in cities (urban foraging) is likely an important, but understudied human-nature interaction globally. As large European cities are critically understudied in this regard, we performed in-depth ethnography-based interviews in Berlin, Germany, to shed light on the cultural background of foragers, their motivations and which plants and fungi are gathered for which purposes. Results demonstrate multiple uses of 125 taxa, mostly frequently-occurring species but also some Red List species, from a range of formal and informal greenspace types. Both native and non-native species were gathered, with significant differences in use patterns. Use for food was most common, followed by medicinal uses, and personal enjoyment was a frequent motivation, indicating that urban foraging combines provisioning and cultural ecosystem services. Familial and childhood foraging exposure were common, pointing to influences of early-in-life exposure on later-in-life activities and transgenerational aspects of the practice. Results further suggest legacy effects from the post-war and communist eras on foraging knowledge. Although non-commercial foraging is allowed in Berlin, over-harvesting was not evident. Interviews indicate that stewardship of urban biodiversity is common among foragers. Results thus suggest considering urban foraging as a promising vehicle for linking humans with nature when developing a biodiverse urban green infrastructure.
\end{abstract}

Keywords: biocultural diversity; edible weeds; endangered plant species; gathering activity; provisioning ecosystem services; urban biodiversity; urban collecting; urban greenspace; urban NTFPs; wild food

\section{Introduction}

The benefits that greenspaces in cities provide to human city dwellers have been conceptualized as urban ecosystem services [1,2]. They can be divided into supporting services, e.g., [3,4], regulating services, e.g., [5,6], provisioning services [7] and cultural services, e.g., [8]. The ascendency of urban agriculture over the past 20 or so years has re-introduced cities, and the greenspaces within them, as places that can successfully provide provisioning services (sustenance) to urban residents across the globe, with variation in cultural and geographical contexts [9]. Largely overlooked, however, is another provisioning practice that takes advantage of already-existing cultivated and wild-growing vegetation in greenspaces: urban foraging [10].

Urban foraging can be described as the gathering of raw biological resources (e.g., plants and plant parts, fungi) in urban and peri-urban areas for food, medicine, crafts, small-scale sale or other purposes [10]. These "forageables" include wild and domesticated species that occur spontaneously, those that spread or persist without human intervention and those that are introduced primarily for non-edible/material purposes, such as landscaping [11]. Urban foraging (also called 'urban gathering' or 'urban collecting') can occur in a wide variety of spaces, both managed and unmanaged, public and 
private, including parks and forests, abandoned lots, alongside streets and in nature preserves [10,12]. It thus relies on the role of formal and informal urban greenspaces in harboring considerable biological richness [4,13], which in addition to maintaining, regulating and supporting ecosystem services, also include a wealth of forageable species for humans.

In 2012, McLain et al. [14] identified urban foraging as a potentially ubiquitous, but largely overlooked phenomenon. In more recent years, a young, but growing body of research has added considerably to the few pre-existing studies, e.g., [15-17]. Cumulatively, the results confirm that urban foraging is an "everyday" (i.e., regular or normal) and surprisingly common practice, both in the Global North $[11,18,19]$ and South [20-22]: For example, in a robust household survey study, Robbins et al. [23] found that almost $18 \%$ of randomly selected residents in four New England states (USA) foraged regularly; more than half of gatherers lived in cities, among them both poorer and wealthier populations. In the city of Kampala (Uganda), $47 \%$ of respondents gathered urban wild plants, many of them relying on them as part of their livelihoods and traditions [24]. An analysis of five U.S.-based studies showed that the demographics of urban foragers cut across common categories, such as ethnicity, sex and income level [12]. Additionally, in many industrialized countries, foraging in general seems to have recently entered popular culture, with a proliferation of websites, books and popular articles on the topic and elite restaurants showcasing foraged ingredients on their menus, e.g., [14,25]. Importantly, while urban residents with limited economic means also gather natural products, the practice is generally not seen by them (or others) as a last resort for subsistence [24, 26] — even though during crises, such as war, wild-growing products in cities have been relied upon for subsistence [27,28].

Despite the growing urban foraging literature, important knowledge gaps remain. For example, while it seems to be a ubiquitous practice in cities around the world [10], to date, much of the research, especially in the context of the industrialized world, is concentrated in the USA, e.g., [11,12,19]. In Europe, despite a wealth of ethnobotanical studies in rural areas and small towns, e.g., [29-31], research from urban areas, where about 70\% of the population lives [32], is sparse. Konijnendijk [33] explains that throughout history, urban forests in Northern and Eastern Europe have provided products such as wood, game and other food. However, more specific information beyond wood procurement and the mentioning of mushroom gathering is not provided. Other European studies have documented that various immigrant groups forage in urban woodlands [34], pointing to urban foraging's potential for supporting biocultural diversity [35]. In Berlin (Germany), 12\% of people's activities in two park sites were interactions with individual plant species, with gathering as the most common of these interactions [18]. A recent questionnaire-based study in five European cities revealed that up to $12 \%$ of respondents go to urban parks predominantly to gather natural products [36].

While recent studies confirm that urban foraging also matters in larger European cities, insights into the sociocultural background, gathering practices and motivations of foragers are largely missing. Such information, however, is needed to understand the social and ecological implications of foraging activities in a regional context [10] and could support the incorporation of foraging into urban policy and management to explicitly support sustainability goals [12]. This study employs in-depth ethnography-based interviews with foragers in the city-an approach successfully employed by, e.g., Poe et al. [11], to investigate foundational questions about the practice. While Palliwoda et al. [18] focused on discerning Berlin park visitors' interactions with individual plant species in two parks, this study explicitly explores the sociocultural backgrounds and motivations of urban foragers in-depth while also investigating which species are collected city-wide in a broad range of habitat types and relating these to the city's total species pool. In addition to developing a more complete picture of urban foraging locally, the research also allows for detailed comparisons between Berlin, an example of a large European city, and urban areas elsewhere. In particular, we address the following research questions:

(1) Who forages in Berlin, how did they learn, how long have they been foraging and where did they grow up (e.g., urban or rural)? 
(2) What is harvested, where and for which uses? Do foragers encounter any barriers to gathering?

(3) Why do Berliners forage, what motivates them and how do they view the activity? Do foraged goods contribute to personal economies (e.g., through food supplementation, sale, guided tours)? What immaterial benefits does foraging provide?

\section{Materials and Methods}

\subsection{Study Area}

Berlin, Germany's capital and most populous city, covers $891 \mathrm{~km}^{2}$ [37] and is home to about 3.7 million people [38]. Average population density city-wide is $41 \mathrm{p} / \mathrm{ha}$, which is in the middle range for German and European cities. However, within the inner city, population density is $117 \mathrm{p} / \mathrm{ha}$, which is above average for European inner cities [39]. Quite ethnically diverse, about 690,000 foreign-born residents live in Berlin, making up almost 19\% of the total population [38].

Berlin is known as a very "green" city. Close to $1 / 3$ of the city area consists of public greenspaces or forest-13\% and $18.4 \%$, respectively - with an additional 6000 ha of water bodies and 3800 ha of agricultural areas [40]. Most public greenspaces are "green and recreational areas" (45.2\%) or allotment gardens (25.8\%) [41]. Moreover, other vegetated areas may be relevant for urban foraging such as informal greenspaces like empty lots and abandoned land. Finally, street trees make up an important part of the green infrastructure of Berlin (438,000 in total, about 82 per kilometer of street) [42].

\subsection{Interviews}

Data about urban foraging in Berlin was gathered primarily through in-depth semi-structured interviews with 11 adult urban foragers, which were completed in-person from mid-May through late August 2017. Our respondents showed a strong female bias, which may not reflect the total pool of urban foragers; however, an earlier Berlin study indicated that more women than men interact with urban biodiversity [18]. Interview data were supplemented by participant-observation during three guided foraging tours within the city. These data-gathering approaches, which have a basis in the ethnographic tradition, have an established precedent in the literature. For example, five U.S.-based urban foraging studies relied on in-depth interviewing techniques, and three included time spent in direct participant-observation of foraging [12]. Ethnographic methods have been shown to be especially effective in studying everyday interactions between people and nature $[14,43]$ and obtaining an "insider's view" of foraging practices [25].

As a start, analysis of known urban foraging studies was completed, e.g., [11,12,16,18]. Data gathered in these studies were categorized and knowledge gaps identified. Interview questions were selected to gather information that would be comparable to studies from other countries and add to research done in Berlin by Palliwoda et al. [18]. An interview template from Pierce [25] was used as a starting point for interview design and question formulation. Though Pierce's study was not exclusively urban foraging research, the type of information gathered and general organization seemed suited to the goals identified for this project. The drafted interview guide included both open-ended and closed-ended questions and was divided into four sections: (1) foraging background, motivations and significance; (2) species harvested; (3) local ecological knowledge, interaction with managers and resource stewardship; and (4) demographic/background information. Two pre-test interviews were done, and some minor adjustments were made to the final version (Appendixs A and B).

Purposive, or targeted, sampling can be useful when information from a specific population group is sought (in this case, foragers in Berlin) and is widely used in ethnobotanical research [44]. Additionally, several urban foraging studies have also used snowball sampling to access participants, e.g., [12], which can provide access to communities that are not immediately accessible or public [25]. Therefore, both sampling techniques were used to recruit participants. Online, visible Berlin-based foragers (those leading tours, writing foraging blogs, etc.) were contacted through email or social media (purposive sampling). A short letter with a description of the project, its goals and a request 
for participation was included as an attachment; four participants were found using this pathway. Personal social networks assisted in setting up four additional interviewing opportunities. At the end of each interview, participants were asked if they could recommend other urban foragers who might be willing to participate (snowball sampling), leading to two more interview opportunities. In one case, an interviewee was already known to the researcher; however, in general, previously unknown participants were preferred. In total, 11 interviews were conducted; 13 people either declined to be interviewed or did not respond when contacted.

An attempt was made to determine beforehand if an interviewee fulfilled two criteria: residence in Berlin and active foraging of wild-growing plants within the city. One person, for example, was excluded since he gathered herbs primarily in tended gardens. Especially "professional" (those that derived income from foraging-related activities), but also "casual" foragers were sought if they had substantial gathering experiences within the last year.

Interviews took place in a variety of locations, including a participant's home, nearby café, university campus and outside sitting in a park. Nine interviews were conducted in German and two in English. The length of interviews varied and was especially dependent on a question that assessed the number and potential uses of species harvested, since each one was often discussed. Excluding this section, the "core" interview usually lasted about $1 / 2 \mathrm{~h}$. The "species harvested" section could add an additional twenty minutes to one hour to the total interview time. All subjects gave their informed consent for inclusion in the project prior to the interview, and everyone agreed to be digitally recorded. Hand-written notes were also taken during each session.

\subsection{Participant-Observation}

In their research, Poe et al. [11] and Pierce [25] found it helpful to join foraging excursions and foraging-related public meetings as participant-observers to overcome some of the limitations that interviews can present. During this study, three guided tours in different parts of the city were attended, which included approximately 80 participants in total. The age range of tour participants was estimated to between 10 and 60 years. Notes were taken on species harvested, conversations and discussions within the group and other observations. Harvested species, parts used, uses and location were added to the harvested species dataset gained from in-depth interviews; other notes and observations provided important fodder for general insights.

\subsection{Digital Database}

Following each interview, data were input into a digital database; hand-written notes were relied upon in this initial phase. Each interview was later listened to in its entirety for missed, corrective and otherwise relevant information, and selected parts were transcribed. If important information was unclear or incomplete, the respective interviewee was contacted; follow-up data were provided by six participants. Data organization and response categorization depended on the type of question. Where appropriate, answers to closed-ended questions were grouped together into discrete categories (e.g., age started foraging was translated to child (0-12), adolescent (13-17) or adult (18+)). Responses to open-ended questions were written out and compared across all interviews; similar answers were then grouped under common themes, and remaining unique answers were assigned to an "other" category (e.g., hindrances to foraging were grouped into "pollution", "private property", etc.).

Interviewees provided a range of descriptive information about where they grew up, including type of settlement (e.g., small village, town, city), its name and the general location. For this study, the type of environment was classified as either urban or rural. An urban designation was assigned if someone said they grew up in a city (including Berlin) or on the edge (Rand) of a city. A rural designation was assigned to other types of settlements, such as village (Dorf) or small city (Kleinstadt). 


\subsection{Taxa Recording, Identification and Compilation}

Information about species harvested was first input into a separate database for each respondent. Botanical name, German and English common name, part collected (leaves, blossoms, fleshy fruit (i.e., excluding nuts/seeds), nuts/seeds, roots, aboveground parts, other), use of each collected part (food, medicine, other) and location harvested (if shared) was input, along with any additional notes. In addition, specific products made from a gathered part were recorded (e.g., jam made from fruit).

Mostly, respondents referred to foraged species by a common name (German or English), which was the starting point for identifying the species. Various methods were used to increase the confidence level of positive identification. First, clarifying questions were asked during interviews. Second, online searches using the mentioned common name provided more information, including a possible botanical name. Third, in cases of ambiguity, efforts were made to contact the interviewees for clarification. Finally, experts on Berlin's flora were consulted during the process and reviewed the final taxa list. All plant species were checked in the Berliner Florenatlas [45], which documents occurrence of all known wild-growing plants in Berlin, to determine if they have been found within the city. This approach allowed for each mentioned plant or fungus to be narrowed down to the species or genera level. Following Synk et al. [19], the total taxa count included all distinct species and genera.

The Florenatlas provided the German common names used and native or non-native status in the city. Following the convention in the Atlas, native plants and archaeophytes (pre-1500 introductions) are merged as native; non-native plants are those introduced post-1500. Botanical names came from the Florenliste von Deutschland, a regularly updated list of currently-accepted names [46]. English common names of plants were taken from the Royal Horticultural Society's "find a plant" web application [47] or the United States Department of Agriculture's PLANTS Database [48] when the former did not include the species.

Fungi identification followed a similar pathway. Once a species was identified from the mentioned common name, the occurrence was established for Berlin via the German Mycological Association's web application [49]. Accepted botanical and German common names were obtained from the same website, while English common names from the British Mycological Society [50] were used.

A master taxa list was compiled by merging same species/taxa, summing the number of mentions and compiling descriptive data. Sometimes, there was uncertainty about the species, either at the species level (e.g., two similar and related species are found in Berlin), or identification could only be determined to the genus level. In these cases, identification was left at the genus level. In the case of closely related (or perhaps the same) species, where one entry could be determined to the species level (e.g., Equisetum arvense) due to an interviewee's response, but another only to a genus level (e.g., Equisetum spec.), the two were merged together in the final table at the species level. One species was removed from the final list since it may not grow wild in the region outside of a tended garden. All unique taxa were counted, along with the number of mentions, parts used and their respective use categories. Moreover, information on lifeform (e.g., classification as tree, herb, fungi), harvest location(s) and Red List threatened status in Berlin [51] were included in the final data table.

\subsection{Use Categories}

Urban foraging studies have categorized plant uses variably. For example, Mollee et al. [24] simply categorized each species as either food or medicine, while Poe et al. [11] also included some products (e.g., vinegar) and other uses (e.g., weaving, spiritual). Responses during interviews were variable; sometimes a specific end-product was mentioned (e.g., scented pillow, syrup, schnapps), other times more general use categories (e.g., food, medicine, tea). In the end, 'food', 'medicine' and 'other' were the final categories chosen. Any product that was consumed without a specifically mentioned medicinal purpose was included in the food category (e.g., tea, liqueur, flavored vinegar, syrup, jam, spice). Specific uses/products in the 'other' category were retained. 


\subsection{Salient Quotes}

In-depth interviews provided a rich source of information painting a vivid and complex picture of each forager's "world". Following other studies on urban foraging, e.g., [12], salient remarks and passages were transcribed and used to illustrate common themes.

\subsection{Statistical Analyses}

We used Pearson's chi-squared test with Yates' continuity correction to test for significant differences between (A) life form, i.e., the proportion of herbs vs. woody species, and (B) species status, i.e., the proportion of native vs. non-native species within (I) the gathered plants and the total flora of Berlin, (II) collected plant parts of the gathered species, such as leaves, blossoms and fleshy fruit, and (III) uses of the gathered species, such as for food, medicine and other uses. If the expected frequencies were determined to be lower than five in some subcategories, we used Fisher's exact test to test for differences between the above-listed frequencies. Statistical analyses concentrated on the findings on vascular plants, i.e., fungi taxa were not included in the statistical analyses. All analyses were conducted using open-source R statistical software [52].

\section{Results}

\subsection{Who Forages?}

Eleven adult urban foragers were interviewed; $72 \%$ were female, and $27 \%$ were male. Age ranged from 28-66, with a median of 37, and most were non-students (72\%). Almost everyone (91\%) was born in Germany including the former German Democratic Republic (GDR), though 40\% of German-born respondents had at least one family member (parent and/or grandparent) who came from another country. More than half (64\%) reported earning income from foraging-related activities, chiefly through workshops and tours, and to a lesser degree from the small-scale sale of value-added or raw products such as bi-annually at outdoor markets. Interviewees were Berlin residents and generally had been for some time, from 5.5-38 years, with a median of 19, and lived in half of Berlin's 12 districts.

Urban and rural childhood environments were equally represented, both with $45 \%$, plus one person who moved between the two. Most people (72\%) started foraging as children, $18 \%$ as adolescents (around the age of 17 ) and only $9 \%$ as an adult. The majority $(64 \%)$ had at least one family member who gathers/gathered. For example, a woman who grew up in the GDR shortly after the Second World War described how during her youth, foraging was a familiar and widespread activity:

There were a lot of us kids and we always traveled to natural places with our parents on the weekends, so I tried a lot of things along the side of the trails [... ] we were always asking our grandma, our mom and other people, 'can you eat that'? That is, we were with other people and other kids. We knew things that are not so common today... It was just normal.

\subsection{Gathered Taxa}

This study identified 125 unique plant and fungi taxa collected within Berlin (Appendixs $C$ and D). This included 120 taxa recorded during interviews $(\max =55, \min =6$, median $=18)$ and five more documented during foraging tours. The most commonly gathered species (see Table 1) were common elder (Sambucus nigra), linden (Tilia spec.) and stinging nettle (Urtica dioica). Almost all the taxa (94\%) were vascular plants; the remaining $6 \%$ were fungi. Vascular plants can be further categorized as herbs $(64 \%)$ and woody species $(30 \%)$ with the latter category including trees $(16 \%)$, shrubs $(13 \%)$ and vines $(2 \%)$ (Figure 1a). Native/non-native status in Berlin was established for 104 of the total 118 plant taxa, showing $64 \%$ as native and $36 \%$ as non-native (Figure $1 \mathrm{~b}$ ). Comparing this ratio to that of native vs. non-native species in the entire species pool of Berlin, we determined a significant difference, with proportionately more non-native species gathered (Table 2). Initially, 17 plant species were found on Berlin's Red List of threatened species within the city. Closer investigation determined that six of 
these were most likely feral plants from cultivation (i.e., not threatened), leaving 11 collected species at various levels of threat (Table 3).

Table 1. Most-commonly-gathered taxa in Berlin with frequency of mention (Freq. refers to 11 total respondents), uses and parts used. In total, 125 unique taxa were identified in this study (Appendixs $C$ and D).

\begin{tabular}{|c|c|c|c|c|}
\hline Botanical Name & Common Name & Freq. & Uses & Parts Used \\
\hline Sambucus nigra & common elder & 9 & $\begin{array}{l}\text { Food, medicine, tea, } \\
\text { syrup, vinegar, liqueur, } \\
\text { schnapps, craft }\end{array}$ & Blossoms, fruit, wood \\
\hline Tilia spec. & lime, linden & 9 & Food, medicine, tea & $\begin{array}{l}\text { Leaves, blossoms, } \\
\text { seeds, leaf-buds }\end{array}$ \\
\hline Urtica dioica & stinging nettle & 9 & $\begin{array}{l}\text { Food, medicine, tea, } \\
\text { juice, dye }\end{array}$ & $\begin{array}{l}\text { Leaves, blossoms, } \\
\text { seeds, root, AGP * }\end{array}$ \\
\hline Aegopodium podagraria & goutweed & 7 & Food, medicine & $\begin{array}{l}\text { Leaves, blossoms, } \\
\text { seeds, AGP }\end{array}$ \\
\hline Glechoma hederacea & ground ivy & 6 & Food, medicine, flavoring & Leaves, blossoms, AGP \\
\hline Hypericum perforatum & perforate St John's wort & 6 & Medicine, oil, tea & Leaves, blossoms, AGP \\
\hline Taraxacum sect. Ruderalia & common dandelion & 6 & $\begin{array}{l}\text { Food, medicine, tea, "honey", } \\
\text { jelly, syrup, schnapps, "coffee" }\end{array}$ & $\begin{array}{l}\text { Leaves, blossoms, } \\
\text { root, flower stalk }\end{array}$ \\
\hline Achillea millefolium agg. & common yarrow & 5 & Food, medicine, tea & Leaves, blossoms \\
\hline Humulus lupulus & hop & 5 & Food, tea, sleeping pillow & $\begin{array}{l}\text { Blossoms, } \\
\text { young shoots }\end{array}$ \\
\hline Juglans regia & common walnut & 5 & Food, insect repellant & Fruit, nut \\
\hline $\begin{array}{l}\text { Melilotus spec. } \\
\text { (M. officinalis } \\
\text { or M. albus) }\end{array}$ & melilot & 5 & $\begin{array}{l}\text { Food, medicine, syrup, } \\
\text { vinegar, liqueur }\end{array}$ & Blossoms, AGP \\
\hline Rosa canina agg. & dog rose & 5 & $\begin{array}{l}\text { Food, medicine, liqueur, } \\
\text { jam, tea }\end{array}$ & Blossoms, fruit, seeds \\
\hline Alliaria petiolata & $\begin{array}{l}\text { Jack-by-the-hedge, } \\
\text { garlic mustard }\end{array}$ & 4 & Food, spice, flavoring & $\begin{array}{l}\text { Leaves, seeds, } \\
\text { root, AGP }\end{array}$ \\
\hline Allium paradoxum & quaint garlic & 4 & Food & Leaves \\
\hline Artemisia vulgaris & mugwort & 4 & $\begin{array}{l}\text { Food, medicine, smudge, } \\
\text { tea, vinegar, herb spread }\end{array}$ & $\begin{array}{l}\text { Leaves, blossoms, } \\
\text { root, AGP }\end{array}$ \\
\hline Betula pendula & silver birch & 4 & Food, medicine, tea, beverage & Leaves, sap water \\
\hline Corylus avellana & hazel & 4 & Food & Leaves, nuts \\
\hline Fagus sylvatica & common beech & 4 & Food & Leaves, nuts \\
\hline Geum urbanum & herb bennet & 4 & Food, flavoring/spice & Leaves, root \\
\hline Plantago lanceolata & narrowleaf plantain & 4 & Food, medicine, syrup & Leaves, seeds \\
\hline Robinia pseudoacacia & false acacia, black locust & 4 & Food & Blossoms, leaves \\
\hline Rumex acetosa ** & common sorrel & 4 & Food & Leaves \\
\hline Stellaria media & chickweed & 4 & Food, food coloring & AGP \\
\hline
\end{tabular}
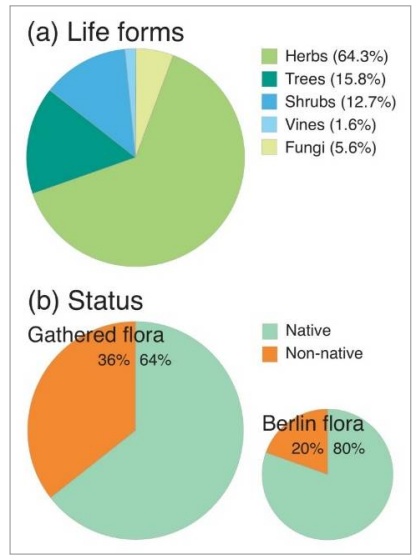

Figure 1. Total gathered taxa in Berlin: (a) separated by life form/growth habit category; and (b) separated by status $(n=104)$ as native or non-native to Berlin (Gathered flora; left) compared with the entire established plant species pool in the city (Berlin flora; right). 
Table 2. Number of the gathered flora, collected plant parts and their uses, differentiated for (A) herbs and woody species and (B) native and non-native species. Statistical differences between the categories were assessed by $\mathrm{Chi}^{2}$ and Fisher's tests, whereas the frequencies within the categories of herbs/woody species and natives/non-natives were compared for (I) the gathered flora vs. the Berlin flora, (II) the collected plant parts, leaves, flowers and fruit, and (III) the uses of gathered plants, food, medicine or other purposes. NA, not applicable, as information on frequencies within life form categories for the total flora of Berlin is missing; n.s., no significant difference detected.

\begin{tabular}{|c|c|c|c|c|}
\hline & \multicolumn{2}{|c|}{ (A) Life Forms } & \multicolumn{2}{|c|}{ (B) Status } \\
\hline & Herbs & Woody Species & Natives & Non-Natives \\
\hline \multicolumn{5}{|l|}{ (I) Flora } \\
\hline Gathered flora & 81 & 38 & 67 & 37 \\
\hline Berlin flora & NA & NA & 1263 & 307 \\
\hline Chi ${ }^{2} ; p$-value (chi ${ }^{2}$ test) & \multicolumn{2}{|c|}{$N A$} & \multicolumn{2}{|c|}{$14.372 ;<0.001$} \\
\hline \multicolumn{5}{|l|}{ (II) Collected parts } \\
\hline Leaves & 43 & 14 & 36 & 11 \\
\hline Blossoms & 42 & 6 & 32 & 10 \\
\hline Fruit & 2 & 21 & 8 & 14 \\
\hline Chi ${ }^{2} ; p$-value (chi ${ }^{2}$ test) & \multicolumn{2}{|c|}{$46.987 ;<0.001$} & \multicolumn{2}{|c|}{$13.101 ;<0.01$} \\
\hline Aboveground parts * & 26 & 1 & 20 & 4 \\
\hline Other plant parts * & 12 & 8 & 11 & 6 \\
\hline Nuts and seeds* & 8 & 7 & 9 & 3 \\
\hline Roots * & 10 & 0 & 8 & 2 \\
\hline \multicolumn{5}{|l|}{ (III) Uses } \\
\hline Food & 72 & 33 & 55 & 36 \\
\hline Medicine & 31 & 14 & 35 & 4 \\
\hline Other & 6 & 2 & 7 & 1 \\
\hline p-value (Fisher's test) & \multicolumn{2}{|c|}{ All comparisons: $n . s}$. & \multicolumn{2}{|c|}{ Comparison Food-Medicine: $<0.001$; otherwise n.s. } \\
\hline
\end{tabular}

Table 3. Gathered plant species on Berlin's Red List of threatened species with Red List category [51] and frequency of mention by respondents (Freq. of Mention refers to 11 total respondents).

\begin{tabular}{lcc}
\hline Botanical Name & Berlin Red List Category & Freq. of Mention \\
\hline Chenopodium bonus-henricus $_{\text {Origanum vulgare * }}$ & Extinct (0) & 1 \\
Taxus baccata * $_{\text {Galium odoratum * }}^{*}$ & Extinct (0) & 1 \\
Nasturtium officinale s. 1. & Extinct (0) & 1 \\
Bistorta officinalis & Critically endangered (1) & 3 \\
Hyoscyamus niger & Endangered (2) & 1 \\
Valeriana officinalis s. 1. & Endangered (2) & 1 \\
Barbarea vulgaris & Endangered (2) & 1 \\
Myrrhis odorata & Threat unknown (G) & 1 \\
Cardamine pratensis & Threat unknown (G) & 1 \\
Centaurea cyanus * & Rare (R) & 1 \\
Fragaria vesca * & Vulnerable (V) & 1 \\
Geum rivale & Vulnerable (V) & 1 \\
Rumex acetosa $* *$ & Vulnerable (V) & 1 \\
Solidago virgaurea & Vulnerable (V) & 1 \\
Thymus pulegioides subsp. pulegioides & Vulnerable (V) & 4 \\
\hline
\end{tabular}

* Most likely feral plants descending from cultivation, i.e., not threatened species; ** likely to include non-threatened species Rumex thyrsiflorus.

Twenty distinct plant/fungus parts were collected for food, medicine and other purposes-representing a wide variety of products and involved plant parts (see examples in Table 1). Leaves (28\%) and blossoms (23\%) are the most-collected parts, followed by aboveground parts (13\%), fruit $(11 \%)$, nuts/seeds $(7 \%)$, roots $(5 \%)$ and mushrooms/conks $(3 \%)$. Our analyses showed that foragers gathered leaves and blossoms especially from herbs, and fruit mainly from woody species, with a significant difference in the corresponding ratios (Table 2). Similarly, comparatively more native species were gathered for their leaves and flowers, but more non-native species for their fruit (Table 2). 
Many plants provide multiple useful parts; leaves and flowers, in particular, are collected from the same taxa $(n=25$; Figure 2a).

Gathered plant parts and their uses

(a) Gathered plant parts

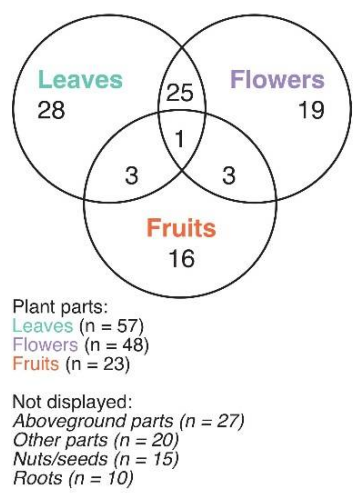

(b) Multiple uses of gathered plant parts

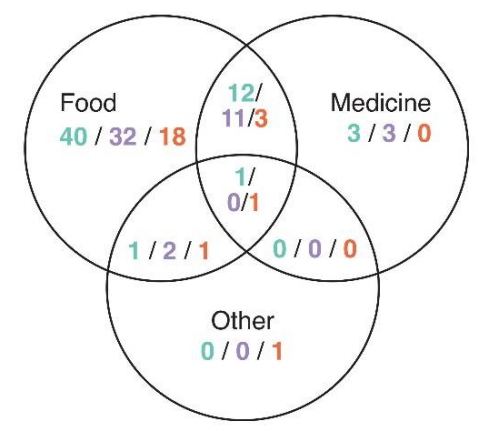

Figure 2. Gathered plant parts and their uses (Venn diagram). (a) Often, urban foragers gathered leaves, blossoms and fruits, as well as other aboveground parts. In many cases, one plant species serves as the source for both harvestable leaves and blossoms. (b) Gathered plants are most popular for food (including beverages such as tea). If a species was utilized for medicine, it also often served as food. Rarely were reported taxa employed for other uses such as insect repellent (see Table 1 for examples).

Food uses were by far the most common (92\%; Tables 1 and 2) and quite diverse. For example, in addition to direct consumption of raw or cooked parts, syrup, "coffee", schnapps (alcohol), jam and flavored salt, among others, were mentioned. Medicinal uses (37\%) were next, followed by other uses (6\%); examples of which included crafts, dye and insect repellent. Close to $1 / 3$ of taxa occupied multiple use categories, and plants were especially used both for food and medicinal purposes (Figure 2b). We detected no significant difference in plant uses between herbs and woody species; however, there was a significant difference between native and non-native species for the comparison between their uses as food and medicine, with proportionally more non-natives gathered for food compared to medicinal purposes (Table 2).

\subsection{Foraging Spaces}

In Berlin, gathering occurs in a wide variety of greenspaces on public and private property. These include parks, forests, cemeteries, courtyards (Höfe), school grounds, around allotment gardens and in abandoned ones, margins of sports fields, alongside streets, landscaping areas, abandoned lands and open spaces along the former East/West Berlin border. Some information about gathering location was provided for $44 \%$ of foraged taxa. Planned and regular visits to specific sites for desired forageables, as well as spontaneous activities were mentioned. Spontaneous foraging for smaller quantities was noted to occur when a harvestable resource was identified during normal day-to-day activities. Planned outings seemed to be correlated with larger sites that had specific and relatively abundant resources and tended to be located outside of the inner city. In addition to collecting within Berlin's city limits, almost all interviewees (91\%) also gathered in rural locations, as one forager explained:

I get out a lot, visiting friends out in the country. And out there I like gathering more (laughs). That is different than a city park—definitely.

It was often important for respondents that they had a "good feeling" about the place they were harvesting. Foragers had different criteria or strategies, often very person-specific, for deciding where to and where not to forage. Commonly-mentioned attributes of desirable gathering sites included places with less people and more space. 
Various situations and locations were unattractive and avoided. The most-mentioned concern was pollution. Through analysis of answers, the pollution category was broken down into four sub-categories: animal/human waste $(n=11)$, main streets/traffic $(n=8)$, chemicals and misc. $(n=7)$ and trash/garbage $(n=2)$. Other spaces and circumstances avoided included private property $(n=2)$, rural areas where agrochemicals could be used $(n=2)$, as well as plants/plant parts in poor health $(n=1)$. Sometimes, individuals had different opinions about potential foraging locations. For example, though pollution from traffic was a common concern, one forager felt that the benefits of consuming wild-growing plants generally outweighed potential risks, even along main streets.

\subsection{Personal Motivations}

The main motivations for foraging cited by respondents were divided into four categories, where multiple answers by the same person were possible. The most common was food $(72 \%)$, followed by curiosity / fun ( $54 \%$ ) and health (45\%). An "other" category $(36 \%)$ included contact with nature, training, teaching and do-it-yourself (DIY). In some cases, one main reason was cited, but others also seemed to be important. For example, one person mentioned food as their main motivation; however, a closer look at their interview indicated that fun and health could also be important:

Not just to be brave and not because 'Oh, I need that because I'm sick', but simply because it just tastes good. Because I'm in the mood to.

Later, this same person explained:

I also get that it is really good for you, that there is definitely a health aspect to it. That you eat seasonally, which you become aware of.

A common thread that ran through all interviews was simply enjoyment of the activity. Aspects of "discovery" or "adventure" were also important (included in the curiosity/fun category). Though no one explicitly cited economic motivations for foraging, $64 \%$ of interviewees derived some type of income from foraging-related activities, in most cases leading tours and workshops. Satisfaction from helping urban people to connect with nature was often observed, as described by a respondent:

What I find nice is that when people come to a course, for example to a tour, who are often men who are hesitant and have no idea. Then when I see them the next time they say: 'Now I go through the streets and see this and this and this,' which they never noticed before.

\subsection{Social Interactions}

Interviewees variously preferred to gather by themselves (37\%), with others $(18 \%)$ or both equally $(45 \%)$. Most interviewees $(82 \%)$ indicated that they primarily or solely used products for personal use, while at the same time, $73 \%$ explained that they shared foraged products with others, including as gifts, as discussed by one forager:

I also have many plant-knowledgeable friends now, where it's just normal when we give each other pesto made from wild herbs and such ... And sometimes also handmade dried herbal tea mixtures, I have often made those for birthdays.

Along with sharing products, sharing knowledge about foraging was very common, with $91 \%$ of interviewees indicating that they taught others. Sharing activities were on a spectrum from spontaneous and unplanned (pointing out a plant to someone spontaneously) to more "official" and organized (leading organized walks or workshops or maintaining an online blog).

\subsection{Stewardship Practices and Observed Change}

Around half (45\%) of respondents mentioned actively taking care of plants (e.g., pruning fruit trees, scattering seeds), while the same amount indicated they did not, with $9 \%$ non-reported. Everyone, 
however, mentioned self-imposed "rules" or guiding practices that they pay attention to when foraging in the city. The most often-mentioned practice concerned limiting the amount harvested from one place (e.g., "Don't take too much.", "Spread the harvest around."). This was closely followed by a similar category, leaving enough to reproduce, when someone specifically mentioned that a motivation for a practice was to protect species' populations (e.g., "Leave small stands alone to reproduce; leave roots when harvesting leaves."). See Table 4 for a full list of categories.

Table 4. Guiding practices for foraging described by respondents, by category and frequency of mention (multiple entries possible).

\begin{tabular}{lc}
\hline \multicolumn{1}{c}{ "Rules" for Harvest } & Frequency of Mention \\
\hline Limit harvest (don't take too much) & 7 \\
Leave enough to reproduce & 5 \\
Harvest healthy plants & 4 \\
Use product (don't waste) & 3 \\
Correct identification & 2 \\
Correct state of mind & 2 \\
Educate others & 2 \\
Method of harvest & 1 \\
Think of other people & 1 \\
"Mundräuber" rules * & 1 \\
\hline
\end{tabular}

* As outlined on the foraging web platform mundraub.org: (1) not on private property; (2) be mindful/respectful towards the tree, surroundings and wildlife; (3) only harvest for personal use (i.e., non-commercial); (4) share the harvest and give something back (e.g., by sharing the location); and (5) be active in the care and planting of fruit trees (adapted translation).

The majority of foragers (64\%) noticed changes occurring over time in places where they harvest. These included observations that some desired plant species stands had increased (Allium paradoxum, Allium ursinum), while others had moved around (Hypericum perforatum, Diplotaxis tenuifolia, Oenothera biennis) or even dramatically decreased (Galium odoratum, Scutellaria galericulata). Changes were generally attributed to natural (if sometimes mysterious) processes or large-scale trends (e.g., wetland shrinkage) and not attributed to foraging activities.

\subsection{Greenspace Manager Interactions}

Interactions with greenspace managers (or the potential thereof) were usually not reported to form a major barrier or play a prominent role for foragers. Nevertheless, about $1 / 3$ mentioned their occurrence. Experienced "professional" foragers indicated they were aware of regulations regarding foraging on public and private land. Two people who led tours sought explicit permission to harvest in certain locations. In one case, park managers were concerned that harvesting a certain species would deplete a stand and asked a forager not to show or harvest it. However, after a year, the stand increased, and permission was given to continue to forage in the location.

\section{Discussion}

While urban foraging is generally addressed as an important, but underestimated human-nature interaction in cities [10], most studies on urban foraging are from the U.S., e.g., [11,19], with some exceptions from large cities in other parts of the world, e.g., [21,22,24]. Gathering wild plants also matters in European cities [18,36]. Yet, this is likely the first study on the topic that uses in-depth ethnography-based interviews, an approach successfully established previously [12], to explore fundamental questions about foraging in Berlin as a model for a large, Western European city. The main insights from this study are:

- As in previous studies, foragers in Berlin use a significant share of the wild flora for multiple reasons in a range of greenspaces; this study adds some novel insights into foraging patterns related to native vs. non-native species and highly abundant vs. rare species.

- Foragers seem to get intimately involved with the existing urban biodiversity and readily share knowledge about useful species with others, including how to avoid negative impacts of gathering 
plants. This adds evidence to studies from the U.S. that claim positive effects of foraging on the stewardship of urban nature [53] and indicate a broader geographical reach of this phenomenon.

- Foraging in Berlin is often a social process, linking people within families and beyond. Most of the interviewed foragers had family members who gathered and also shared their knowledge with others. Hereby, our study ultimately suggested that foraging functions as a cross-generational memory carrier of knowledge about biodiversity as: (i) the majority of interviewees started foraging as children themselves; and (ii) knowledge is passed on to the next generation and the larger community by the foragers involved in this study. Results suggest that childhood familiarity with gathering can influence later-in-life continuation of the practice. Interestingly, this process also bridges experience across political systems. Some responses about foraging practices indicate legacy effects of World War Two and the early post-war years, as well as the German Democratic Republic (GDR), when Berlin, and Germany as a whole, was divided into a communist and a capitalist political regime.

\subsection{What? Collected Taxa}

With 125 taxa documented, this study expands the palette of species foraged within Berlin considerably. Previously, Palliwoda et al. [18] identified 59 taxa through observations in two parks. Thirty-two of these overlap with this study, leaving 93 newly-documented taxa, or a combined total of 149 , which makes up $10 \%$ of the total 1527 established wild plant species in Berlin [51]. Referring to the usable species pool though, in New York City, $82 \%$ of woody plant species could potentially provide at least one forageable resource [54], while in Seattle, a total of 486 gathered species (plant and fungus) constituted $50 \%$ of the usable species pool. Detailed data on the Berlin flora, i.e., frequency of wild plant species, native vs. non-native status, Red List status [45,51], allow this study to gain novel insights into how gathered species relate to the total urban species pool:

(i) Both native and non-native species were being used (non-natives even more so) with significant differences in some usage patterns (Table 2);

(ii) Ubiquitous species were likely to be harvested, as 18 of the 23 most-commonly-occurring wild plant species (excluding grasses) were collected; nine of which were "salient species" mentioned by at least four respondents (e.g., Sambucus nigra, Urtica dioica, Table 1);

(iii) Exceptionally, also some red-listed species were gathered, although most of these were collected in places where they likely had been previously established by humans (e.g., Origanum vulgare); however, also a few remnant natural populations of endangered species were foraged (e.g., Nasturtium officinale, Table 3).

Six of the most frequently-collected species were also shown by Palliwoda et al. [18] to be frequently-gathered species. Some species are collected in multiple cities. For example, Alliaria petiolata is commonly collected in Berlin, where it is native, but also as a non-native species in both New York and Philadelphia [12]. Further research into "cosmopolitan" species gathered in cities across the globe could provide fruitful insights into similarities and differences between foraging activities internationally, especially as urban floras become more homogenous due to urbanization processes, e.g., [55,56]. Ailanthus altissima (tree of heaven), for example, originally native to China, is today a widespread metropolitan tree worldwide [57]. Leaves, bark and other parts of the plant are used in traditional Chinese medicine [58], and leaves have been reported as an emergency food in the Western world [54,59]. Surprisingly, one respondent reported the use of Ailanthus altissima bark as a medicine for resilience to urban stressors. Whether such links between traditional uses in the native and current uses within the non-native range of a species are a random result or indicate inter-cultural knowledge transfer remains an open, but interesting question, as today, many large cities share a set of cosmopolitan species.

As in other studies [11,12], food uses of gathered taxa were most common $(92 \%)$. However, the harvest of fruits, nuts and berries—products that play prominently in other studies $[19,24]$ —were 
mentioned less. Together, they comprised only $24 \%$ of all foraged parts, while leaves, blossoms and aboveground parts made up $64 \%$. Concerns about urban pollution have been cited as a possible explanation for the lower occurrences of urban food-plant foraging, including "leafy greens" that grow closer to the ground [24]. Pollution risks do exist close to main roads in Berlin [60], and this has obviously been realized by most gatherers who preferred a broad range of other habitats. While $64 \%$ of gathered plants were herbaceous species growing close to the ground, respondents did mention harvesting products higher up (like tree fruits/nuts), particularly in places where people and pets were common.

Notably, decorative floral arrangements and arts and crafts uses were rarer than in other studies [11,18,23]. In addition, mushrooms and other fungi were gathered $(n=7)$, but less commonly compared with other studies in temperate cities ([11] $n=53,[19] n=29)$.

\subsection{Who? Urban Foragers}

That nearly $3 / 4$ of respondents cited childhood foraging experiences indicates that early-in-life exposure to foraging can be connected to later-in-life capacity and desire to continue the practice, including in urban areas. It was common that respondents described actively expanding their childhood knowledge of forageable species as they grew older. Teenagers who foraged for more natural things as children had an increased sense of biodiversity [61], and childhood play experiences in wild environments have been correlated with positive perceptions of natural environments and outdoor recreation activities later in life [62]. Relatedly, almost $2 / 3$ of respondents had a family member who foraged; two respondents with children described foraging with them; and children also took part in one of the foraging tours. These findings point to the intergenerational aspects of the practice and its potential for transmitting cultural traditions and ecological knowledge [11]. Respondents equally grew up in rural and urban environments, tentatively supporting the findings by Mollee et al. [24] that a rural background does not necessarily result in higher urban collection events, as has been posited by other researchers [63]. The urban/rural classification method used in this study is approximate and possibly even under-represents urban childhood environments.

The cultural diversity described in some U.S.-based studies $[12,64]$ was not found to the same extent, as $91 \%$ of respondents were born in Germany, but $40 \%$ of these individuals had a family member (parent or grandparent) who was born elsewhere. In Freiburg (Germany), Jay and Schraml [34] found that Russian-Germans and immigrants from Balkan states gathered natural products in urban woodlands, and in Berlin, Palliwoda et al. [18] documented a Thai and an Iranian forager. Non-German participants on two of the three foraging tours, reports from respondents and personal observations support this hypothesis, as well. Possibly, first generation migrants were underrepresented in this study because of the targeting techniques used and subsequent snowball sampling. As Jay and Schraml [34] note, studies in Europe on the ties between migrants and nature are rare. Indeed, a recent European study revealed that migrants of the first generation, but not the following generations, showed some differences in using urban greenspaces compared to other people [36]. Future research to access a more diverse selection of urban foragers is thus needed, for Berlin and other European cities [30]. This is especially relevant in Germany following the European migrant crisis, which peaked in 2015, when 1.1 million people immigrated to the country [65].

Interestingly, some relationships between immigration and respondents' foraging activities can still be seen, particularly when looking back into recent history. For example, one respondent who grew up following the Second World War described learning about edible plants and fungi from (then) recent immigrants, who, "... spoke German, only a different dialect." During and especially after the war, a mass migration of ethnic Germans who were settled in Eastern and southeastern Europe occurred. Expelled from these areas, many migrated to Germany [66]. It could be that they brought unique knowledge of edible and medicinal plants and fungi with them; knowledge that would have been especially useful during the difficult years following the war. Konijendijk [33] corroborates that mushroom gathering in Germany was influenced by an influx of migrants from Eastern Europe after 
the war. Another respondent explained how her grandparents (ethnic Germans (Danube Swabians) from Ukraine who came to Germany during the war) used to forage: "Out of necessity, I think, is why they did it before." Once they were in a better economic situation, they did not continue the practice, despite running a farm in a rural area where there must have been opportunities.

It could also be that in general, during the post-war period, people needed to gather wild-growing foods and therefore knowledge of forageable resources was retained or grew, even without influences from recent immigrants. People have relied on wild resources during war and times of crisis $[27,28,30]$ including in Germany [67], sometimes leading them to be stigmatized as foods of famine and therefore later discontinued [68]. However, while some wild resource gathering fades, other resources with a higher cultural appreciation value continue to be gathered [31]. The more recent rise in interest about foraging (and urban foraging in particular) points towards a changing relationship between people and these wild plants and fungi [25], where there is now a growing longing for wild foods [30]. Another culturally-mediated influence of foraging behavior could be connected to policies during the German Democratic Republic (GDR) times (1949-1989). Dried medicinal plants were accepted at collection points (Sammelstelle), and people, including children, could earn some pocket money in exchange.

This study thus suggests that the still relatively recent post-war era and the GDR times in Germany have left imprints on current-day foraging behaviors and knowledge and could be fruitful areas for further research [69]. In addition, since foraging is back en vogue, there are opportunities for the sharing and documentation of culturally-significant practices from these times before this unique knowledge is lost. Urban foraging in Berlin is thus a good example of biocultural diversity, an evolving perspective to understand how people with different cultural backgrounds live with biodiversity, also in cities [35].

\subsection{How? Resource Stewardship}

Threats to urban biodiversity from wild harvesting have been documented, specifically when the products are destined for the cash-based informal economy [20,70]. Conversely, gathering traditional medicine plants in urban greenspaces lessened pressures on nearby conservation lands [16]. Our study revealed that also non-commercial foraging activities utilize some red-listed plant species in Berlin (Table 3). However, each of the cases of concern should be investigated individually to determine if there is indeed a realistic threat from foraging. Allium ursinum, previously listed as critically endangered in Berlin [71], is an illustrative example. Foragers described harvesting it in one specific place (Botanischer Volkspark Blankenfelde-Pankow). The location was described as one of the only places where the plant grew in Berlin, but also as a place where gathering (for personal use) was allowed. Foragers observed that over the years, the population has expanded, even while the overall popularity of gathering there has grown. The species is no longer listed on the most current Red List of threatened species [51]. Other plants have suffered a different fate. For example, two respondents discussed species that have disappeared from harvesting locations. While they are not on the Red List, it is important to determine if foraging could have a negative impact on populations or exacerbate larger patterns of disappearance.

As a rule, however, most respondents were cautious about harvesting, sensitive of limited resources and seemed to have adapted their activities accordingly (Table 4). Additionally, easy-to-understand harvesting "rules" such as those outlined on web platforms or communicated in workshops and tours might help to prevent negative impacts of urban foraging practices. This highlights the importance of voluntary codes of conduct, which were also evident in a recent study from Seattle, revealing "internal moral calculations" as an important mechanism while accessing edible plants [64]. The authors thus conclude that voluntary codes of conduct are the best way to manage urban foraging within cities and to help to prevent overharvesting [64]. Yet, in our study, some foragers were aware of changing population sizes of some species (not necessarily red-listed plants), but excluded foraging as a possible underlying mechanism. While there is no evidence of foraging as a 
driver of decreasing populations of species of conservation concern in Berlin, our results suggest that sharing further information on rare plant species with foragers may be promising in increasing their sensitivity for negative impacts on such species. This is especially important when urban foraging also involves commercial aspects that may not coincide with sustainable consumption [72].

\section{Conclusions}

While urban foraging is surprisingly widespread in cities around the world, it is still an understudied phenomenon [10]. Our study confirms some results from North American studies on main foraging patterns for a large European metropole. It further adds new insights into how gathered plants relate to the total city flora, in particular concerning the native vs. non-native status and the Red List status of gathered species.

In the U.S. and beyond, gathering from public urban greenspaces is often officially prohibited; this legal situation has been reported as a major foraging barrier [10,12,73]. Importantly, in Germany, gathering for personal use and in small quantities is generally permitted on public lands by the Federal Conservation Act [74]. The Berlin case thus suggests that over-foraging does not take place under such legal regulations. This insight can encourage urban policies that allow non-commercial foraging activities in cities. Incorporating urban foraging into urban planning processes and goals can contribute to a sustainable urban development of large European cities, and elsewhere. For example, land managers and planning initiatives could easily support urban foraging practices by including edible species in local green planning, such as planting easy-to-recognize berry bushes. In Germany, the "edible city" initiative of Andernach is an illustrative example. There, edible plants are grown in public greenspaces where people are encouraged to harvest for free, resulting in a better diet and increased social interaction [75]. As seen in other research, Berlin's foragers are an enthusiastic and dedicated "community of practice" [11], who utilize a considerable number of forageable species from a wide spectrum of urban greenspaces. Sustainable urban development needs stewardship of urban people for their green environments in general, and in particular for biodiversity $[35,76]$. Urban foraging obviously raises awareness of and engagement with the existing urban biodiversity, simply by using it $[53,61]$.

There are different pathways towards implementation. Foraging approaches can be integrated in environmental education as illustrated by the concept of the "biodiverse edible school" that seeks to involve both cultivated and wild-growing edible plants in environmental and food education [77]. Approaches towards biodiversity-friendly management of green spaces [78] can be enriched by practices that contribute to offering a wide selection of forageable resources and gathering niches for urban foragers. In addition, potential alliances between greenspace managers and foragers could leverage their unique knowledge and expertise as enthusiastic and committed stewards of biodiverse and productive urban greenspaces to realize common goals. For example, stewardship practices employed by urban foragers are often identical to those employed by restoration volunteers [53]. There are thus promising opportunities to harness the multitude of ecological and social benefits that greenspaces deliver by incorporating urban foraging into the agenda of developing green infrastructure for sustainable cities.

Author Contributions: J.L.L.-Y., I.K. and L.K.F. conceived of and designed the field study. J.L.L.-Y. performed the field study. J.L.L.-Y. and L.K.F. analyzed the data. J.L.L.-Y. wrote the paper, to which I.K. and L.K.F. contributed.

Funding: This work was partially financed by the "Green Infrastructure and Urban Biodiversity for Sustainable Urban Development and the Green Economy (GREEN SURGE)", EU FP7 collaborative project, FP7-ENV.2013.6.2-5-603567 (Grant Agreement No. 603567).

Acknowledgments: We thank all interviewees for volunteering their information, insights and time and Birgit Seitz for sharing her knowledge of Berlin's flora. We acknowledge support by the Open Access Publication Funds of Technische Universität Berlin.

Conflicts of Interest: The authors declare no conflict of interest. 


\section{Appendix A. Foraging Interview Guide}

(1) Foraging Background, Motivations, Significance

- Are there plants or fungi that you gather in Berlin (aside from in a private garden)? Plants/fungi are understood as those that can be eaten or used or other purposes, e.g., fruit, nuts, mushrooms, salad, jams, tea, crafts, decoration, firewood.

- How did get into foraging/gathering wild plants? How and when (age) did you learn to gather? In Berlin?

- Does anyone else in your family gather? Did you learn from them?

- What would you say your main motivation is for gathering?
Food
Health
Interest/Curiosity
Political Reasons
Economic reasons
Other

- Do you prefer to gather alone or with others?

- Do you teach others?

- Do you harvest primarily for your own use? Do you share with others? If so, what kinds of products?

(2) Species harvested (See recording sheet below)

(3) Local Ecological Knowledge, Interaction with Managers, Resource Stewardship

- Have you noticed any change in places where you harvest over time?

- Are there places in Berlin that you would NOT harvest in? Why not?

- Have you had interactions with land managers/other gatherers where you gather? If so, please explain.

- Do you have any harvest "rules" you follow (re-seeding, selective harvest, etc.)?

- Do you do anything to tend the plants (e.g., fertilizing, pruning, spreading seed, keeping them a secret?)

(4) Demographics/Background Information

- Age

- $\quad$ Sex (Male, Female, Other)

- Where were you born?

- Do you have ancestors/family members that come from outside of Germany?

- How long have you lived in Berlin?

- In which neighborhood (Stadtteil) do you live in?

- What do you do for a living? Full time or part time?

(5) Other

- Are there any other important things we haven't discussed about your gathering practices/is there anything else you would like to add?

- Do you know any other "urban foragers" in Berlin that you would be willing to put me in touch with? 
Appendix B. Sample Species Recording Sheet

Table A1. Sample Species Recording Sheet.

\begin{tabular}{|c|c|c|c|c|c|c|c|c|c|}
\hline Interview No: & & & & & t(s) $\mathrm{Ha}$ & /Use Category & & & \\
\hline Species & Leaves & Blossoms & Fruit & Nuts/Seeds & Roots & Aboveground Parts & Other Parts & Places Harvested & Notes \\
\hline
\end{tabular}




\section{Appendix C. Vascular Plants Gathered by Foragers in Berlin, Germany}

Table A2. Vascular Plants Gathered by Foragers in Berlin, Germany. Identified through in-person interviews and participant-observation.

\begin{tabular}{|c|c|c|}
\hline Botanical Name & Common Name (German) & Common Name (English) \\
\hline Abies spec. & Tanne & fir \\
\hline Acer platanoides* & Spitz-Ahorn & Norway maple \\
\hline Achillea millefolium agg. & Gemeine Schafgarbe & common yarrow \\
\hline Aegopodium podagraria & Giersch & goutweed \\
\hline Ailanthus altissima & Götterbaum & tree of heaven \\
\hline Alliaria petiolata & Knoblauchsrauke & Jack-by-the-hedge, garlic mustard \\
\hline Allium paradoxum & Seltsamer Lauch, Wunder-Lauch & quaint garlic \\
\hline Allium schoenoprasum & Echter Schnittlauch & chives \\
\hline Allium ursinum & Bär-Lauch & ramsons \\
\hline Amelanchier ovalis & Gemeine Felsenbirne & snowy mespilus \\
\hline Anchusa officinalis & Gebräuchliche Ochsenzunge & alkanet \\
\hline Arctium lappa & Große Klette & greater burdock \\
\hline Artemisia vulgaris & Gewöhnlicher Beifuß & mugwort \\
\hline Athyrium filix-femina & Gemeiner Frauenfarn & lady fern \\
\hline Atriplex spec. & Melde & Atriplex \\
\hline Barbarea vulgaris & $\begin{array}{l}\text { Echte Winterkresse, } \\
\text { Gewöhnliches Barbarakraut }\end{array}$ & winter cress \\
\hline Bellis perennis & Gänseblümchen & daisy \\
\hline Berberis vulgaris & Gemeine Berberitze & common barberry \\
\hline Berteroa incana & Graukresse & alyssum \\
\hline Betula pendula & Hänge-Birke & silver birch \\
\hline Bistorta officinalis & Schlangen-Wiesenknöterich & bistort \\
\hline Campanula spec. & Glockenblume & bellflower \\
\hline Capsella bursa-pastoris & Gemeines Hirtentäschel & shepherd's purse \\
\hline Cardamine pratensis & Wiesen-Schaumkraut & cuckoo flower \\
\hline Centaurea cyanus & Kornblume & bachelor's buttons \\
\hline Chaenomeles spec. & Zierquitte & ornamental quince \\
\hline Chelidonium majus & Großes Schöllkraut & greater celandine \\
\hline Chenopodium album & Weißer Gänsefuß & fat hen \\
\hline Chenopodium bonus-henricus & Guter Heinrich & good King Henry \\
\hline Cichorium intybus & Wegwarte & chicory \\
\hline Cirsium spec. & Distel & thistle \\
\hline Claytonia perfoliata & Tellerkraut & spring beauty, miner's lettuce \\
\hline Cornus mas & Kornelkirsche & Cornelian cherry \\
\hline Corydalis spec. & Lerchensporn & Corydalis \\
\hline Corylus avellana & Gemeine Hasel & hazel \\
\hline Corylus colurna & Baum-Hasel & Turkish hazel \\
\hline Diplotaxis tenuifolia & $\begin{array}{l}\text { Schmalblättriger Doppelsame, } \\
\text { Wilde Rucola }\end{array}$ & perennial wall rocket \\
\hline Echium vulgare & Gemeiner Natternkopf & viper's bugloss \\
\hline Equisetum arvense* & Acker-Schachtelhalm & field horsetail \\
\hline Fagus sylvatica & Rotbuche & common beech \\
\hline Fallopia japonica & Japanischer Flügelknöterich & Japanese knotweed \\
\hline Ficaria verna & Scharbockskraut & lesser celandine \\
\hline Filipendula ulmaria & Echtes Mädesüß & meadowsweet \\
\hline Fragaria vesca & Wald-Erdbeere & wild strawberry \\
\hline Galeobdolon luteum & Gewöhnliche Goldnessel & yellow archangel \\
\hline Galinsoga parviflora & Kleinblütiges Franzosenkraut & gallant soldier \\
\hline Galium album & Wiesen-Labkraut & hedge bedstraw \\
\hline Galium aparine & Kletten-Labkraut & cleavers \\
\hline Galium odoratum & Waldmeister & sweet woodruff \\
\hline Galium verum & Echtes Labkraut & lady's bedstraw \\
\hline Geum rivale & Bach-Nelkenwurz & water avens \\
\hline Geum urbanum & Echte Nelkenwurz & herb bennet \\
\hline Ginkgo biloba & Ginkgo & maidenhair tree, ginkgo \\
\hline Glechoma hederacea & Gundermann & ground ivy \\
\hline Hedera helix & Gemeiner Efeu & ivy \\
\hline Helianthus annuus & Sonnenblume & sunflower \\
\hline Helianthus tuberosus & Topinambur & Jerusalem artichoke \\
\hline Heracleum sphondylium & Wiesen-Bärenklau & hogweed, eltrot \\
\hline Hippophae rhamnoides & Sanddorn & sea buckthorn \\
\hline Humulus lupulus & Gemeiner Hopfen & hop \\
\hline Hyoscyamus niger & Schwarzes Bilsenkraut & henbane \\
\hline Hypericum perforatum & Johanniskraut & perforate St John's wort \\
\hline Juglans regia & Echte Walnuss & common walnut \\
\hline Lamium spec. & Taubnessel & Dead-Nettle \\
\hline Lepidium latifolium & Breitblättrige Kresse & dittander \\
\hline Leucanthemum vulgare s. 1. & Wiesen-Margerite & ox-eye daisy \\
\hline Lycium barbarum or L. chinense & $\begin{array}{l}\text { Gemeiner Bocksdorn or } \\
\text { Chinesischer Bocksdorn, Goji }\end{array}$ & Chinese box thorn, goji \\
\hline Lysimachia nummularia & Pfennigkraut & creeping Jenny \\
\hline Mahonia aquifolium & Mahonie & Oregon grape \\
\hline Malus spec. & Apfel & apple \\
\hline
\end{tabular}


Table A2. Cont.

\begin{tabular}{|c|c|c|}
\hline Botanical Name & Common Name (German) & Common Name (English) \\
\hline Malva sylvestris subsp. sylvestris* & Wilde Malve & common mallow \\
\hline Melilotus albus & Weißer Steinklee & white melilot \\
\hline Melilotus officinalis & Echter Steinklee & ribbed melilot \\
\hline Melilotus spec. ${ }^{* *}$ & Steinklee & melilot \\
\hline Morus spec. & Maulbeere & mulberry \\
\hline Myosotis spec. & Vergissmeinnicht & forget-me-not \\
\hline Myrrhis odorata & Süßdolde & sweet cicely \\
\hline Nasturtium officinale s. 1. & Brunnenkresse & common watercress \\
\hline Oenothera biennis agg. & Gewöhnliche Nachtkerze & common evening primrose \\
\hline Origanum vulgare & Gemeiner Dost & oregano \\
\hline Oxalis spec. & Sauerklee & Oxalis \\
\hline Papaver spec. & Mohn & poppy \\
\hline Pastinaca sativa subsp. sativa & Pastinak & wild parsnip \\
\hline Plantago lanceolata & Spitz-Wegerich & narrowleaf plantain \\
\hline Plantago major s. 1. & Breit-Wegerich & common plantain \\
\hline Portulaca oleracea & Portulak & little hogweed, common purslane \\
\hline Potentilla anserina & Gänse-Fingerkraut & silverweed cinquefoil \\
\hline Potentilla reptans & Kriechendes Fingerkraut & creeping cinquefoil \\
\hline Prunus avium or P. cerasus & Kirsche & cherry \\
\hline Prunus cerasifera & Kirschpflaume & cherry plum \\
\hline Prunus domestica & Pflaume, Mirabelle & European plum, mirabelle plum \\
\hline Prunus persica & Pfirsich & peach \\
\hline Prunus spinosa s. 1. & Schlehe & blackthorn \\
\hline Quercus spec. & Eiche & oak \\
\hline Robinia pseudoacacia & Robinie & false acacia, black locust \\
\hline Rosa canina agg. & Hunds-Rose, Hecken-Rose & dog rose \\
\hline Rubus spec. & Brombeere & blackberry \\
\hline Rumex acetosa * & Wiesen-Sauerampfer & common sorrel \\
\hline Salix spec. & Weide & willow \\
\hline Sambucus nigra & Schwarzer Holunder & common elder \\
\hline Saponaria officinalis & Echtes Seifenkraut & soapwort \\
\hline Scutellaria galericulata & Gemeines Helmkraut & common skullcap \\
\hline Solanum dulcamara & Bittersüßer Nachtschatten & bittersweet \\
\hline Solidago canadensis & Kanadische Goldrute & golden plume, Canada goldenrod \\
\hline Solidago virgaurea & Gemeine Goldrute & European goldenrod \\
\hline Sorbus aucuparia & Eberesche, Vogelbeere & rowan \\
\hline Stellaria media & Gewöhnliche Vogelmiere & chickweed \\
\hline Symphytum officinale & Gewöhnlicher Beinwell & common comfrey \\
\hline Syringa vulgaris & Gemeiner Flieder & lilac \\
\hline Taraxacum sect. Ruderalia & Wiesen-Löwenzähne & common dandelion \\
\hline Taxus baccata & Eibe & common yew \\
\hline Thlaspi arvense & Acker-Hellerkraut & field pennycress \\
\hline $\begin{array}{l}\text { Thymus pulegioides subsp. } \\
\text { pulegioides }\end{array}$ & Gemeiner Thymian & broad-leaved thyme \\
\hline Tilia spec. & Linde & lime, linden \\
\hline Urtica dioica & Große Brennessel & stinging nettle \\
\hline Vaccinium myrtillus & Heidelbeere & common bilberry \\
\hline Valeriana officinalis s. 1. & Arznei-Baldrian & common valerian \\
\hline Viola arvensis subsp. arvensis & Feld-Stiefmütterchen & field pansy \\
\hline Viola spec. & Veilchen & violet \\
\hline
\end{tabular}

* Also includes citation(s) for genus only; ${ }^{* *}$ not counted as a unique species, but included individually for the analyses

\section{Appendix D. Fungi Gathered by Foragers in Berlin, Germany}

Table A3. Fungi Gathered by Foragers in Berlin, Germany. Identified through in-person interviews and participant-observation.

\begin{tabular}{ccc}
\hline Botanical Name & Common Name (German) & Common Name (English) \\
\hline Auricularia auricula-judae & Judasohr & jelly ear \\
Boletus edulis & Steinpilz & penny bun \\
chantharellus cibarius & Pfifferling & chanter \\
Ganoderma lucidum & Glänzender Lackporling, Reishi & lacquered bracket, reishi \\
Inonotus obliquus & Schiefer Schillerporling, Chaga & chaga \\
Laetiporus sulphureus & Schwefelporling & chicken of the woods \\
Morchella elata & Hohe Morchel & black morel \\
\hline
\end{tabular}




\section{References}

1. Bolund, P.; Hunhammar, S. Ecosystem services in urban areas. Ecol. Econ. 1999, 29, 293-301. [CrossRef]

2. Haase, D.; Larondelle, N.; Andersson, E.; Artmann, M.; Borgström, S.; Breuste, J.; Gomez-Baggethun, E.; Gren, A.; Hamstead, Z.; Hansen, R.; et al. A quantitative review of urban ecosystem service assessments: Concepts, models, and implementation. AMBIO 2014, 43, 413-433. [CrossRef] [PubMed]

3. Imhoff, M.L.; Bounoua, L.; DeFries, R.; Lawrence, W.T.; Stutzer, D.; Tucker, C.J.; Ricketts, T. The consequences of urban land transformation on net primary productivity in the United States. Remote Sens. Environ. 2004, 89, 434-443. [CrossRef]

4. Nielsen, A.B.; van den Bosch, M.; Maruthaveeran, S.; Konijnendijk van den Bosch, C.C. Species richness in urban parks and its drivers: A review of empirical evidence. Urban Ecosyst. 2014, 17, 305-327. [CrossRef]

5. Xiao, Q.; McPherson, E.G.; Simpson, J.R.; Ustin, S.L. Rainfall Interception by Sacramento's Urban Forest. J. Arboric. 1998, 24, 235-244.

6. Mariani, L.; Parisi, S.G.; Cola, G.; Lafortezza, R.; Colangelo, G.; Sanesi, G. Climatological analysis of the mitigating effect of vegetation on the urban heat island of Milan, Italy. Sci. Total Environ. 2016, 569-570, 762-773. [CrossRef] [PubMed]

7. Russo, A.; Escobedo, F.J.; Cirella, G.T.; Zerbe, S. Edible green infrastructure: An approach and review of provisioning ecosystem services and disservices in urban environments. Agric. Ecosyst. Environ. 2017, 242, 53-66. [CrossRef]

8. Bertram, C.; Rehdanz, K. Preferences for cultural urban ecosystem services: Comparing attitudes, perception, and use. Ecosyst. Serv. 2015, 12, 187-199. [CrossRef]

9. Eigenbrod, C.; Gruda, N. Urban vegetable for food security in cities. A review. Agron. Sustain. Dev. 2015, 35, 483-498. [CrossRef]

10. Shackleton, C.; Hurley, P.; Dahlberg, A.; Emery, M.; Nagendra, H. Urban foraging: A ubiquitous human practice overlooked by urban planners, policy, and research. Sustainability 2017, 9, 1884. [CrossRef]

11. Poe, M.R.; McLain, R.J.; Emery, M.; Hurley, P.T. Urban forest justice and the rights to wild foods, medicines, and materials in the city. Hum. Ecol. 2013, 41, 409-422. [CrossRef]

12. McLain, R.J.; Hurley, P.T.; Emery, M.R.; Poe, M.R. Gathering "wild" food in the city: Rethinking the role of foraging in urban ecosystem planning and management. Local Environ. 2014, 19, 220-240. [CrossRef]

13. Kowarik, I. Novel urban ecosystems, biodiversity, and conservation. Environ. Pollut. 2011, 159, $1974-1983$. [CrossRef] [PubMed]

14. McLain, R.J.; MacFarland, K.; Brody, L.; Hebert, J.; Hurley, P.; Poe, M.; Buttolph, L.P.; Gabriel, N.; Dzuna, M.; Emery, M.R.; et al. Gathering in the City: An Annotated Bibliography and Review of the Literature about Human-Plant Interactions in Urban Ecosystems; U.S. Department of Agriculture, Forest Service, Pacific Northwest Research Station: Portland, OR, USA, 2012.

15. Terada, T.; Yokohari, M.; Bolthouse, J.; Tanaka, N. "Refueling” Satoyama woodland restoration in Japan: Enhancing restoration practice and experiences through woodfuel utilization. Nat. Cult. 2010, 5, 251-276. [CrossRef]

16. Wehi, P.M.; Wehi, W.L. Traditional plant harvesting in contemporary fragmented and urban landscapes. Conserv. Biol. 2010, 24, 594-604. [CrossRef] [PubMed]

17. Grabbatin, B.; Hurley, P.T.; Halfacre, A. "I still have the old tradition": The co-production of sweetgrass basketry and coastal development. Geoforum 2011, 42, 638-649. [CrossRef]

18. Palliwoda, J.; Kowarik, I.; von der Lippe, M. Human-biodiversity interactions in urban parks: The species level matters. Landsc. Urban Plan. 2017, 157, 394-406. [CrossRef]

19. Synk, C.M.; Kim, B.F.; Davis, C.A.; Harding, J.; Rogers, V.; Hurley, P.T.; Emery, M.R.; Nachman, K.E. Gathering Baltimore's bounty: Characterizing behaviors, motivations, and barriers of foragers in an urban ecosystem. Urban For. Urban Green. 2017, 28, 97-102. [CrossRef]

20. Petersen, L.M.; Moll, E.J.; Collins, R.; Hockings, M.T. Development of a compendium of local, wild-harvested species used in the informal economy trade, Cape Town, South Africa. Ecol. Soc. 2012, 17. [CrossRef]

21. Schlesinger, J.; Drescher, A.; Shackleton, C.M. Socio-spatial dynamics in the use of wild natural resources: Evidence from six rapidly growing medium-sized cities in Africa. Appl. Geogr. 2015, 56, 107-115. [CrossRef]

22. Unnikrishnan, H.; Nagendra, H. Privatizing the commons: Impact on ecosystem services in Bangalore's lakes. Urban Ecosyst. 2015, 18, 613-632. [CrossRef] 
23. Robbins, P.; Emery, M.; Rice, J.L. Gathering in Thoreau's backyard: Nontimber forest product harvesting as practice. Area 2008, 40, 265-277. [CrossRef]

24. Mollee, E.; Pouliot, M.; McDonald, M.A. Into the urban wild: Collection of wild urban plants for food and medicine in Kampala, Uganda. Land Use Policy 2017, 63, 67-77. [CrossRef]

25. Pierce, A.R. The Distance from Necessity: A Bourdieusian Analysis of Gathering Practices in Vermont. Ph.D. Thesis, Antioch University New England, Keene, NH, USA, 2014.

26. Potteiger, M. Eating Ecologies: Integrating Productive Ecologies and Foraging at the Landscape Scale. In Localizing Urban Food Strategies. Farming Cities and Performing Rurality, Proceedings of the 7th International Aesop Sustainable Food Planning Conference Proceedings, Torino, Italy, 7-9 October 2015; Cinà, G., Dansero, E., Eds.; Politecnico di Torino: Turin, Italy, 2015; pp. 131-145.

27. Redžić, S. Use of wild and semi-wild edible plants in nutrition and survival of people in 1430 days of siege of Sarajevo during the war in Bosnia and Herzegovina (1992-1995). Coll. Antropol. 2010, 34, 551-570. [PubMed]

28. Sachdeva, S.; Emery, M.R.; Hurley, P.T. Depiction of wild food foraging practices in the media: Impact of the Great Recession. Soc. Nat. Resour. 2018, 31, 977-993. [CrossRef]

29. Redžić, S. Wild edible plants and their traditional use in the human nutrition in Bosnia-Herzegovina. Ecol. Food Nutr. 2006, 45, 189-232. [CrossRef]

30. Łuczaj, Ł.; Pieroni, A.; Tardío, J.; Pardo-de-Santayana, M.; Sõukand, R.; Svanberg, I.; Kalle, R. Wild food plant use in 21st century Europe: The disappearance of old traditions and the search for new cuisines involving wild edibles. Acta Soc. Bot. Pol. 2012, 81, 359-370. [CrossRef]

31. Reyes-García, V.; Menendez-Baceta, G.; Aceituno-Mata, L.; Acosta-Naranjo, R.; Calvet-Mir, L.; Domínguez, P.; Garnatje, T.; Gómez-Baggethun, E.; Molina-Bustamante, M.; Molina, M.; et al. From famine foods to delicatessen: Interpreting trends in the use of wild edible plants through cultural ecosystem services. Ecol. Econ. 2015, 120, 303-311. [CrossRef]

32. United Nations, Department of Economic and Social Affairs, Population Division. World Urbanization Prospects: The 2014 Revision, Highlights; United Nations: New York, NY, USA, 2014; ISBN 978-9-21-151517-6.

33. Konijnendijk, C.C. The Forest and the City: The Cultural Landscape of Urban Woodland; Springer Science + Business Media B.V.: New York, NY, USA, 2008; ISBN 978-1-40-208371-6.

34. Jay, M.; Schraml, U. Understanding the role of urban forests for migrants-Uses, perception and integrative potential. Urban For. Urban Green. 2009, 8, 283-294. [CrossRef]

35. Elands, B.H.M.; Vierikko, K.; Andersson, E.; Fischer, L.K.; Gonçalves, P.; Haase, D.; Kowarik, I.; Luz, A.C.; Niemelä, J.; Santos-Reis, M.; et al. Biocultural diversity: A novel concept to assess human-nature interrelations, nature conservation and stewardship in cities. Urban For. Urban Green. 2018. [CrossRef]

36. Fischer, L.K.; Honold, J.; Botzat, A.; Brinkmeyer, D.; Cvejić, R.; Delshammar, T.; Elands, B.; Haase, D.; Kabisch, N.; Karle, S.J.; et al. Recreational ecosystem services in European cities: Sociocultural and geographical contexts matter for park use. Ecosyst. Serv. 2018. [CrossRef]

37. Amt für Statistik Berlin Brandenburg. Statistiken. Available online: https://www.statistik-berlinbrandenburg.de/statistiken/inhalt-statistiken.asp (accessed on 7 May 2018).

38. Amt für Statistik Berlin-Brandenburg. Statistischer Bericht A I 5-hj 1/17: Einwohnerinnen und Einwohner im Land Berlin am 30. Juni 2017; Amt für Statistik Berlin Brandenburg: Potsdam, Germany, 2017.

39. Senate Department for Urban Development and Housing. Berlin Environmental Atlas. 06.06 Population Density (2017 Edition). Available online: http:/ / www.stadtentwicklung.berlin.de/umwelt/umweltatlas / edm606_01.htm\#fig1 (accessed on 6 May 2018).

40. Senate Department for the Environment, Transport and Climate Protection. Öffentliche Grünflächen in Berlin. Available online: http:/ / www.berlin.de/senuvk/umwelt/stadtgruen/gruenanlagen/de/daten_ fakten/downloads/ausw_7.pdf (accessed on 30 September 2017).

41. Senate Department for the Environment, Transport and Climate Protection. Anteil Öffentlicher Grünflächen in Berlin. Available online: http:/ / www.berlin.de/senuvk/umwelt/stadtgruen/gruenanlagen/de/daten_ fakten/downloads/ausw_5.pdf (accessed on 30 September 2017).

42. Senate Department for the Environment, Transport and Climate Protection. Straßen- und Parkbäume: Übersichten der Bestandsdaten. Available online: https:/ / www.berlin.de/senuvk/umwelt/stadtgruen/ stadtbaeume/de/daten_fakten/uebersichten/index.shtml (accessed on 30 September 2017).

43. Head, L.; Muir, P. Suburban life and the boundaries of nature: Resilience and rupture in Australian backyard gardens. Trans. Inst. Br. Geogr. 2006, 31, 505-524. [CrossRef] 
44. Tongco, D.C. Purposive sampling as a tool for informant selection. Ethnobot. Res. Appl. 2007, 5, 147-158. [CrossRef]

45. Seitz, B.; Ristow, M.; Prasse, R.; Machatzi, B.; Klemm, G.; Böcker, R.; Sukopp, H. Der Berliner Florenatlas; Botanischer Verein von Berlin und Brandenburg 1859 e.V.; Natur + Text: Rangsdorf, Germany, 2012; ISBN 978-3-94-206208-4.

46. Buttler, K.P.; Thieme, M.; Hand, R.; Kämmer, F.; Hodvina, S.; König, A.; Matzke-Hajek, G.; Amarell, U.; von Raab-Straube, E.; Metzing, D.; et al. Florenliste von Deutschland-Gefäßpflanzen, Version 9. Available online: http:/ / www.kp-buttler.de/ (accessed on 6 May 2018).

47. Royal Horticultural Society. Find a Plant. Available online: https://www.rhs.org.uk/plants/search-form (accessed on 21 December 2017).

48. United States Department of Agriculture, Natural Resource Conservation Service. PLANTS Database. Available online: https:/ / plants.usda.gov/java/ (accessed on 21 December 2017).

49. Beyer, H.; Diekow, W.; Gröger, F.; Jarling, R.; Kaspar, R.; Ludwig, E.; Sammler, P.; Schmidt, M. Deutsche Gesellschaft für Mykologie. Available online: http:/ / berlin.pilze-deutschland.de/ (accessed on 21 December 2017).

50. British Mycological Society. English Names for fungi (Mar 2016). Available online: http:/ / www.britmycolsoc. org.uk/library / english-names (accessed on 21 December 2017).

51. Seitz, B.; Ristow, M.; Meißner, J.; Machatzi, B.; Sukopp, H. Rote Liste und Gesamptartenliste der Etablierten Farn- und Blütenpflanzen von Berlin; Der Landesbeauftragte für Naturschutz und Landschaftspflege/Senatsverwaltung für Umwelt, Klima und Verkehr: Berlin, Germany, 2018. [CrossRef]

52. R Core Team. R: The R Project for Statistical Computing. Available online: https://www.R-project.org/ (accessed on 23 April 2018).

53. McLain, R.J.; Poe, M.R.; Urgenson, L.S.; Blahna, D.J.; Buttolph, L.P. Urban non-timber forest products stewardship practices among foragers in Seattle, Washington (USA). Urban For. Urban Green. 2017, 28, 36-42. [CrossRef]

54. Hurley, P.T.; Emery, M.R. Locating provisioning ecosystem services in urban forests: Forageable woody species in New York City, USA. Landsc. Urban Plan. 2018, 170, 266-275. [CrossRef]

55. Kühn, I.; Klotz, S. Urbanization and homogenization-Comparing the floras of urban and rural areas in Germany. Biol. Conserv. 2006, 127, 292-300. [CrossRef]

56. Zeeman, B.J.; McDonnell, M.J.; Kendal, D.; Morgan, J.W. Biotic homogenization in an increasingly urbanized temperate grassland ecosystem. J. Veg. Sci. 2017, 28, 550-561. [CrossRef]

57. Kowarik, I.; Säumel, I. Biological flora of Central Europe: Ailanthus altissima (Mill.) Swingle. Perspect. Plant Ecol. Evol. Syst. 2007, 8, 207-237. [CrossRef]

58. Hu, S.Y. Ailanthus. Arnoldia 1979, 39, 29-50.

59. Fleischhauer, S. Enzyklopädie der Essbaren Wildpflanzen; AT Verlag: Munich, Germany, 2003; ISBN 978-3-85-502889-4.

60. Säumel, I.; Kotsyuk, I.; Hölscher, M.; Lenkereit, C.; Weber, F.; Kowarik, I. How healthy is urban horticulture in high traffic areas? Trace metal concentrations in vegetable crops from plantings within inner city neighbourhoods in Berlin, Germany. Environ. Pollut. 2012, 165, 124-132. [CrossRef] [PubMed]

61. Chipeniuk, R. Childhood foraging as a means of acquiring competent human cognition about biodiversity. Environ. Behav. 1995, 27, 490-512. [CrossRef]

62. Bixler, R.D.; Floyd, M.F.; Hammitt, W.E. Environmental socialization: Quantitative tests of the childhood play hypothesis. Environ. Behav. 2002, 34, 795-818. [CrossRef]

63. Davenport, N.A.; Gambiza, J.; Shackleton, C.M. Use and users of municipal commonage around three small towns in the Eastern Cape, South Africa. J. Environ. Manag. 2011, 92, 1449-1460. [CrossRef] [PubMed]

64. Charnley, S.; McLain, R.J.; Poe, M.R. Natural resource access rights and wrongs: Nontimber forest products gathering in urban environments. Soc. Nat. Resour. 2018, 31, 734-750. [CrossRef]

65. Destatis (Federal Statistics Office). Press Release 246-Immigration and Net Immigration Peaked in 2015. Available online: https:/ /www.destatis.de/EN/PressServices/Press/pr/2016/07/PE16_246_12421.html (accessed on 29 January 2018).

66. Faulenbach, B. Die Vertreibung der Deutschen aus den Gebieten Jenseits von Oder und Neiße. Available online: http:/ / www.bpb.de/geschichte/nationalsozialismus/dossier-nationalsozialismus/39587/ die-vertreibung-der-deutschen (accessed on 9 February 2017). 
67. Häsler, H.; Wünschmann, I. Berliner Pflanzen: Das Wilde Grün der Großstadt; Terra Press: Berlin, Germany, 2009; ISBN 978-3-98-124773-2.

68. Menendez-Baceta, G.; Aceituno-Mata, L.; Tardío, J.; Reyes-García, V.; Pardo-de-Santayana, M. Wild edible plants traditionally gathered in Gorbeialdea (Biscay, Basque Country). Genet. Resour. Crop Evol. 2012, 59, 1329-1347. [CrossRef]

69. Larondelle, N.; Strohbach, M.W. A murmur in the trees to note: Urban legacy effects on fruit trees in Berlin, Germany. Urban For. Urban Green. 2016, 17, 11-15. [CrossRef]

70. Molnár, V.A.; Nagy, T.; Löki, V.; Süveges, K.; Takács, A.; Bódis, J.; Tökölyi, J. Turkish graveyards as refuges for orchids against tuber harvest. Ecol. Evol. 2017, 7, 11257-11264. [CrossRef] [PubMed]

71. Prasse, R.; Ristow, M.; Klemm, G.; Machatzi, B.; Raus, T.; Scholz, H.; Stohr, G.; Sukopp, H.; Zimmermann, F. Liste der wildwachsenden Gefäßpflanzen des Landes Berlin—mit Roter Liste; Senatsverwaltung für Stadtentwicklung/Der Landesbeauftragte für Naturschutz und Landschaftspflege: Berlin, Germany, 2001; ISBN 978-3-88-961137-6.

72. De Jong, A.; Varley, P. Foraging tourism: Critical moments in sustainable consumption. J. Sustain. Tour. 2018, 26, 685-701. [CrossRef]

73. McLain, R.; Poe, M.; Hurley, P.T.; Lecompte-Mastenbrook, J.; Emery, M.R. Producing edible landscapes in Seattle's urban forest. Urban For. Urban Green. 2012, 11, 187-194. [CrossRef]

74. Gesetz über Naturschutz und Landschaftspflege. Available online: http://www.gesetze-im-internet.de/ bnatschg_2009/ (accessed on 30 January 2018).

75. Kosack, L. Die Essbare Stadt Andernach: Urbane Landwirtschaft im öffentlichen Raum. Z. Angew. Geogr. 2016, 40, 138-144. [CrossRef]

76. Buijs, A.E.; Mattijssen, T.J.M.; Van der Jagt, A.P.M.; Ambrose-Oji, B.; Andersson, E.; Elands, B.H.M.; Steen Møller, M. Active citizenship for urban green infrastructure: Fostering the diversity and dynamics of citizen contributions through mosaic governance. Curr. Opin. Environ. Sustain. 2016, 22, 1-6. [CrossRef]

77. Fischer, L.K.; Brinkmeyer, D.; Karle, S.J.; Cremer, K.; Huttner, E.; Seebauer, M.; Nowikow, U.; Schütze, B.; Voigt, P.; Völker, S.; et al. Biodiverse edible schools: Linking healthy food, school gardens and local urban biodiversity. Urban For. Urban Green. 2018. [CrossRef]

78. Aronson, M.F.J.; Lepczyk, C.A.; Evans, K.L.; Goddard, M.A.; Lerman, S.B.; MacIvor, J.S.; Nilon, C.H.; Vargo, T. Biodiversity in the city: Key challenges for urban green space management. Front. Ecol. Environ. 2017, 15, 189-196. [CrossRef] 